\title{
КІНЬ НА ПЕТРОГЛІФАХ БРОНЗОВОГО ВІКУ ЦЕНТРАЛЬНОЇ АЗЇ̈
}

Pеферат: Вивчення наскальних зображень є важливою складовою у реконструкції побуту, вірувань, міфологічних та естетичних уявлень первісної доби. Метою статті є виявлення маркерів культу коня на петрогліфах Центральної Азії. Здійснено аналіз ключових сюжетів петрогліфів, пов'язаних з зображенням коня, зіставлення їх із міфами та ритуальними практиками індоєвропейців, що збереглися у письмових джерелах. Аргументовано висновок, що культ коня остаточно склався у Центральній Азії лише за доби пізньої бронзи. Простежуються кілька етапів формування культу, від сприйняття коня в якості об'єкта полювання до використання як упряжної тварини, що, разом з коліснищею, символізує переміщення бога $і$, насамкінець, до рівня світової тварини, що асоиіюється із ияарем та богами.

Ключові слова: бронзовий вік, сеймінсько-турбінський феномен, петрогліф, культ коня, індоєвропейиі, ашвамедха, Ашвіни-Діоскури.

Вступ. Наскальні зображення є важливим джерелом для реконструкції побуту, вірувань, міфологічних та естетичних уявлень давніх людей. Це джерело стає цінним для вивчення доісторичних реалій Центральної Азії, територія якої була місцем зіткнення Пердньоазійських та Китайської цивілізацій зі світом степових кочовиків. Одним з питань, на яке можуть допомогти дати відповідь петрогліфи, є поширення у цьому регіоні культу коня, що вбачається більшістю археологів одним з маркерів перебування та впливу індоєвропейського блоку культур.

Що стосується географічних меж регіону «Центральна Азія», то вони мають неоднозначне тлумачення і тому часто викликають плутанину в їх визначені. Коливання популяційних процесів, вплив на них різних цивілізаційних центрів, як у його межах, так і поза ними, - стали причиною складності його розмежування. У радянські часи під Центральною Азією розуміли Східний Туркестан, Туву, Забайкалля, Внутрішню та Зовнішню Монголію. Під Середньою Азією розумілися чотири країни - Туркменію, Узбекистан, Таджикистан i Киргизстан. В історико-археологічних дослідженнях до поняття Середня Азія також включали й південно-східну частину Казахстану, виходячи з критерію єдності культурно-історичного розвитку цих регіонів у минулому [Шер 1980, с. 14]. В англомовній літературі термін Центральна Азія в XIX ст. загалом збігався з пізнішим радянським тлумаченням, але протягом XX ст. дефініція поступово змінювалась і під Центральною Азією почали розуміти внутрішньоазійську область від Південного Кавказу на заході до Тибету на сході. Згодом на нараді ЮНЕСКО 1978 р. було вирішено, що під терміном Центральна Азія в історичній ретроспективі має розумітися цивілізації Афганістану, північно-східного Ірану, Пакистану, Північної Індії, західного Китаю, Монголії та колишніх радянських республік Середньої Азії. [Dani et al. 1992, p. 8] Саме це останнє тлумачення терміну, яке, на думку А.Х. Дені та B.M. Массона [Dani, Masson 1992], поєднує симбіоз кочових і хліборобних народів та співвідносяться 3 культурною та історичною реальністю, більш за інші відповідає для розв'язання окреслених у даному досліджені завдань.

Визначення часу нанесення наскальних зображень - запорука правильної або найбільш наближеної до дійсності інтерпретації петрогліфів. Для датування наскальних зображень застосовуються різні методи. Одним з основних методів датування петрогліфів $є$ порівняльностилістичний аналіз, зокрема, за датованим аналогом - предметним зображенням або зразком мистецтва малих форм; за зображеннями будь-яких предметів, що датуються, т. зв. реалій на наскальних малюнках; на основі зіставлення з площинними зображеннями (барвистими або гравірованими), що походять з поховальних (рідше поселенських) комплексів; з урахуванням зв'язку тих чи інших зображень 3 культурним шаром (у разі, якщо біля підніжжя скелі 3 малюнками проводилися археологічні розкопки).

Найменш дискусійні визначення відносної хронології двох або кількох зображень на одній образотворчій площині отримано при аналізі палімпсестів - накладень одних малюнків на інші. При 
цьому слід мати на увазі, що інтервал між часом нанесення пов'язаних таким чином зображень все одно залишається невідомим, тим більше, якщо вони належать до однієї історичної доби.

Останніми роками досить активно використовуються результати мультидисциплінарних методів вивчення петрогліфів, зокрема дані радіокарбонного аналізу. Однак, як зазначив B.I. Молодін: «...на жаль, точність датування природничими методами (хоча за ними, ймовірно, майбутнє) поки не може нас задовольнити» (переклад мій - М.К.) [Молодин и др. 2004 , с.58]. Значні перспективи має застосування методів трасологічного аналізу для 3'ясування техніки нанесення петрогліфів [Савинов 2000, с. 152]. При датуванні петрогліфів також враховують інтенсивність засмаги малюнків на стелі.

Слід враховувати, що у більшості випадків датується якась вибірка зображень, які піддаються більш-менш точним хронологічним визначенням, тоді як основна маса петрогліфів, що знаходяться поруч або залишається фактично недатованою (малюнки просто «прив' язуються» до вже певного історичного періоду), або датується за стилістичними ознаками.

Важливим досягненням у вивчені петрогліфів $є$ виділення стилістичних особливостей зображень, характерних для того чи іншого історичного періоду, або обгрунтованої вибірки стилістично однорідних малюнків, які можна співвідносити 3 тим чи іншим розділом археологічної періодизації. В такий спосіб були виділені петрогліфи карасукського або варчінского стилю доби пізньої бронзи, для більш раннього часу - Ангарського та Минусинського стилів, сеймінсько-турбинська образотворча традиція, для пізніших періодів - наскальні зображення у «стилі оленячих каменів», стилістичні особливості малюнків ранньоскіфського часу (або Аржан-майемірскій стиль) і таштикської культури. Добре «впізнаванні» зображення Окуньовської культури (хоча вони і не утворюють єдиного стилю). Певною стилістичною виразністю характеризуються чудові гравіювання давньотюркського часу [Новгородова 2012, c. 125-135]. Слід також наголосити, що далеко не всі зображення безперечно можна віднести до того чи іншого стилю та по багатьом з них ведуться досить активні суперечки.

Використання такої дрібної систематики не завжди є зручним, тим паче, що культурна атрибуція цих стилів не видається однозначною. Деякі дослідники схиляються до їхнього поділу в межах культурно-історичних блоків культур. Так, А.В. Спімахов і В.А. Новожонов виділяють всього три образотворчі традиції доби бронзи: ямно-афанасіївську, андронівську та карасукську [Таинство 2014, с. 230], що не нівелює всі вади стилістичного аналізу, але дає можливість 3 меншою похибкою відносити їх до певного кола культур.

Дослідження. Метою запропонованого дослідження $\epsilon$ виявлення маркерів культу коня на петрогліфах Центральної Азії. Сам образ коня 3'являється ще за часів палеоліту та пов'язаний власне $з$ диким конем, який вплітався у канву первісного світогляду та був доволі поширеним як в Свропі, так і в Центральній Азії. Нас же цікавлять образи його свійського перевтілення, коли змінюється господарсько-економічне значення цієї тварини для людини та збільшується сакральне навантаження на його духовний еквівалент. Виявити та визначити час появи саме такого нововтілення у петрогліфах є завданням даного дослідження.

Численність наскальних зображень створює видимість сюжетного розмаїття петрогліфів. Насправді, якщо оперувати поняттям образотворчого пласту, кількість повністю повторюваних композицій порівняно невелика. За кожною $з$ них стоїть певний міфологічний (епічний або оповідальний) сюжет, сенс якого може бути розкритий за особливостями самих зображень (іконографія, склад «учасників» тієї чи іншої композиції, взаємопоєднання фігур, специфічні атрибути тощо). Існують і певні семантичні блоки, що розкривають сенс тих чи інших композицій. Так, опозитно розміщені фігури означають протистояння, перевернуті поразку чи смерть, підведені руки - адорацію, кругові композиції - реінкарнацію (відродження), виділення однієї більшої фігури - знак домінування (або багаторазового посилення) даного персонажа і т.п. Системний розгляд таких семантичних блоків дозволяє відійти від свідомо знеособлених універсалій та звернутися до «мови» самого образотворчого джерела [Савинов 2000, с. 157], доповнюючи його, якщо це можливо, письмовими та фольклорними джерелами спільнот, що мешкали або мешкають на цій території. 
Зображення коня - один з найбільш поширених образів на петрогліфах Центральної Азії, починаючи від палеоліту, коли кінь був важливою складовою мисливського промислу, та закінчуючи етнографічним часом. Обриси цієї тварини виникали на скелях означеного регіону, відображаючи їх значимість для авторів цих сюжетів.

Найдавніші зображення коней однозначно інтерпретуються як дикі місцеві коні. Їх виділяють за характерними особливостями: петрогліфи великого розміру, дуже поганої збереженості, зі згладженим контуром, вивітрені та покриті інтенсивною патиною. Виконані вони у точковій техніці неширокою контурною лінією; фігури профільні, статичні, масивні 3 відвислими животами; повна відповідність пропорцій статури; розрізнені та, як правило, не складають композицій; однаковий прийом зображення черева та ніг тварини однією безперервною смугою (рис. 1) [Дэвлет и др. 2011, с. 79; Кубарев 2006, с. 120]. Більшість вчених відносять їх до верхнього палеоліту (Д. Цевеендорж та Е. Якобсон), у деякій опозиції знаходиться гіпотеза В.Д. Кубарева про їх неолітичний і раньобронзовий час [Кубарев 2006, с. 121].

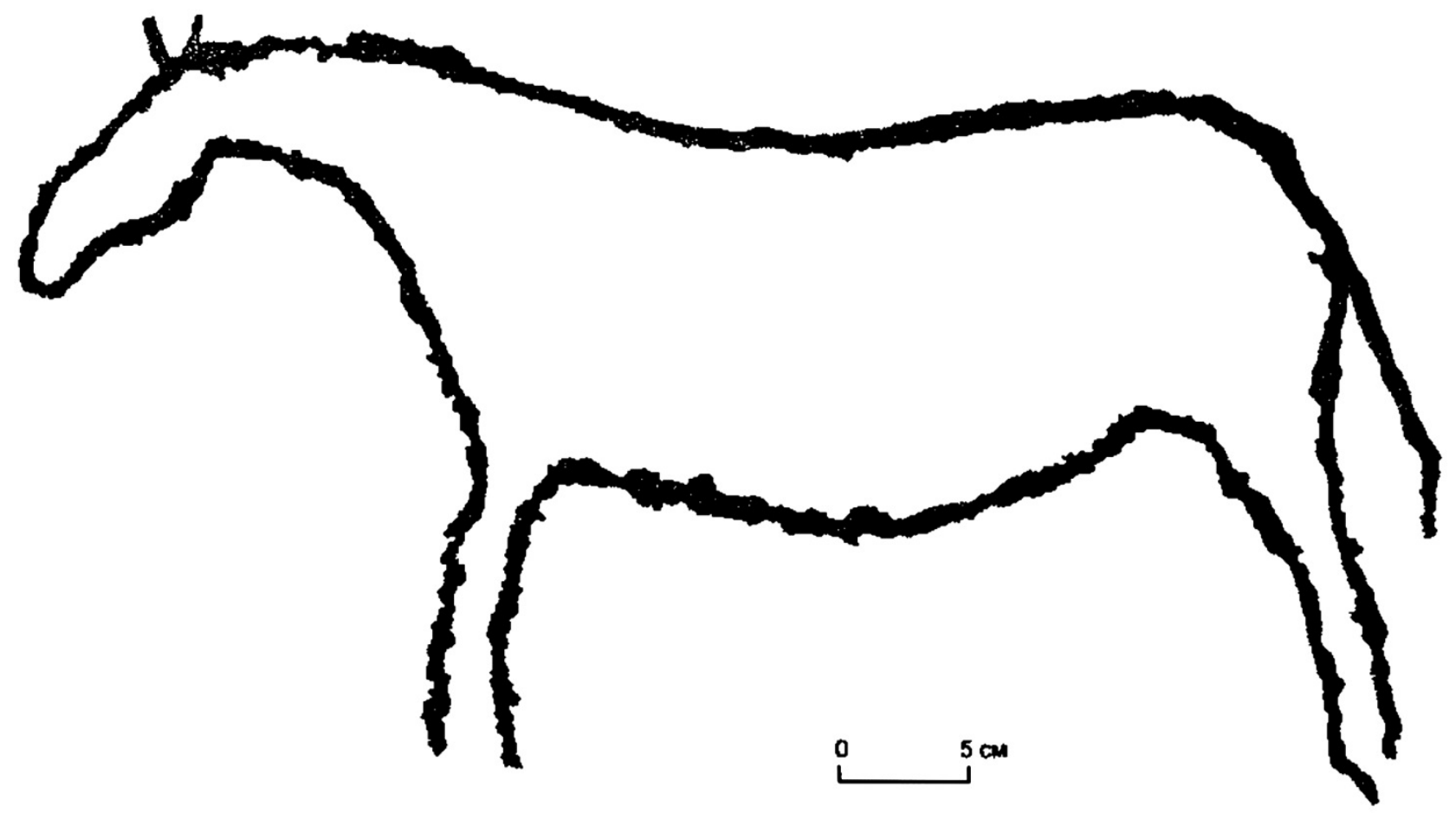

Рис. 1. Зображення коня Калгутинський рудник [за: Археология ... 2009, с. 190-191]

Fig. 1. An image of a horse Kalgutinsky mine [after: Археология ... 2009, c. 190-191]

3 В.Д. Кубаревим можна погодитися в тому сенсі, що зображення коня, як промислової тварини, далеко не завжди можна пояснити ії давністю та відсутністю доместикованого коня. Для цього регіону полювання на диких коней зберігає свою важливість аж до етнографічного часу [Кубарев 2006]. I, дійсно, коня в контексті мисливської здобичі можна побачити на багатьох пам'ятках петрогліфів, що зображуються у різноманітних стилях та належать до різних епох.

Доместикацію коня, як м'ясної тварини, дуже важко зафіксувати на петрогліфах Центральної Азії. Можна навіть з певними умовностями стверджувати: якщо цей етап мав місце у Центральній Азії, він був не настільки значущим, щоби вплинути на первісних митців. Зображення, що за стилістичними ознаками датуються періодом ранньої бронзи, демонструють переважно коня як мисливську здобич. Значна кількість зображень коня з'являється за доби розвинутої бронзи, але поодинокі фігури зазвичай не дають можливості точно вказати, кого відтворював стародавній митець - мисливську здобич чи свійську тварину. Тому головну увагу треба приділити сюжетно-композиційним зображенням.

Всі питання щодо доместикації знімаються з появою колісниць і використанням коня в якості тяглової сили. Образ коня тісно поєднується з самою колісницею та утворює з нею окрему 
смислову одиницю. Зображення колісниць доволі чітко датуються і тому не залишають жодних сумнівів щодо свійського статусу коня. Датують їх зазвичай II та I тис. до н.е. [Новоженов 2012, c. 122]. Коні на наскальних малюнках зображувалися по обидва боки від дишла зверненими спинами один до іншого або, значно рідше, - один над одним (рис. 2) [Новоженов 2012, с. 96].

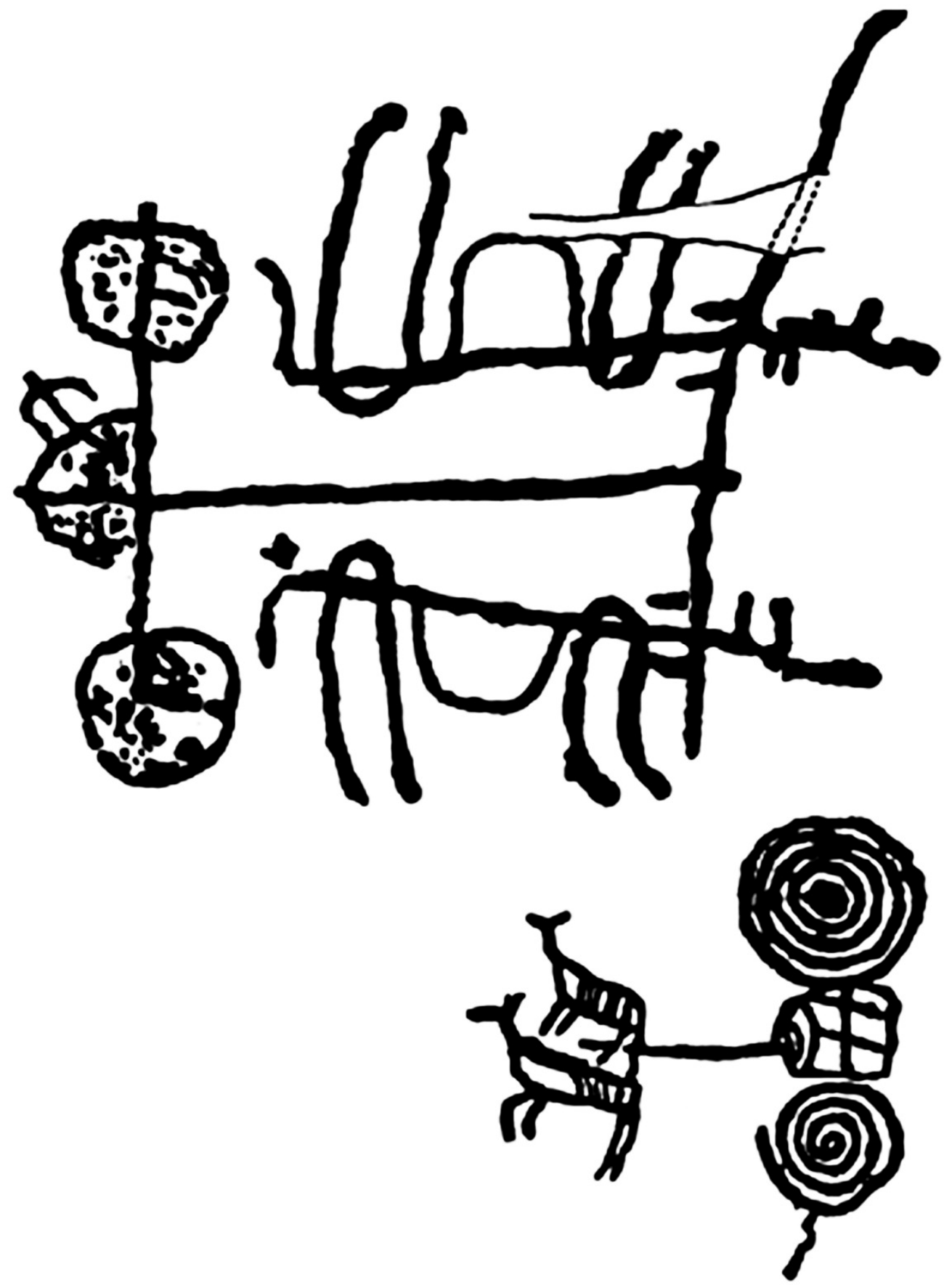

Рис. 2. Колісниці Середнього Снісея

Fig. 2. Chariots, Middle Yenisei

Варто зазначити, що коня, як тяглову тварину, зображено також із возами та двоколками, але він не $\epsilon$ основною твариною для цих засобів пересування і такі зображення трапляються не часто [Новоженов 2012, с. 95].

Різні образотворчі традиції мали свої іконографічні особливості зображення коня. Так, у виділеній В.А. Новожоновим і А.В. Спімаховим андронівській образотворчій традиції особливістю багатьох коней є акцентована грива, що в деяких випадках нависає над головою тварини у вигляді «чуба». Саме так показано коней на бронзових скульптурних наконечниках 
металевих виробів - головним чином кинджалів - 3 пам'яток єлунінсько-сеймінськотурбінського кола, які виокремлені в єдиний тип найбільш яскравих зразків такої зброї [Таинство 2014, с. 230]. Для карасукської образотворчої традиції характерним є відхід від статичності зображень у бік певної схематизації та надання динамізму фігурам. Фігури тварин цього горизонту часто перекривають більш ранні зображення, утворюючи палімпсести, мають характерні іконографічні особливості, а саме: вибиті у «скелетному стилі» і скошені вперед ноги, виділений невеликий трикутний виступ на загривку. Часто можна спостерігати «схематизацію» фігур, загальне спрощення стилю та повну відсутність деталізації зображень. Коней показано без гриви та нависаючого над лобом чуба [Таинство 2014, с. 234].

Від середньої, а особливо від пізньої бронзи починають з'являтися сюжети, які більшістю дослідників інтерпретуються як такі, що передбачають якісь ритуальні дії стосовно коня та можуть бути з деякою умовністю реконструйовані за допомогою письмових джерел $\mathrm{i}$ фольклору. Сюди можна віднести такі сюжетні блоки, як: кінь у світового дерева, небесніфантастичні колісниці, цікаві сюжетно-концептуальні пари кінь-собака, кінь-козел, кінь-змія, зображення коня у вигляді оленя тощо. Важко заперечити, що сюжети, які неодноразово повторюються, несуть в собі якусь міфологічну формулу, котру слід пов'язувати з певною етнічною спільнотою, що існувала в цьому регіоні. Більшість дослідників схильні вважати, що образ коня та пов'язані з ним сюжети, які відомі у більшості народів Свразії, були позичені 3 індоєвропейської традиції [Кузьмина 1997, с. 39; Гамкрелидзе, Иванов 1984, с. 939], до якої відносять певний пласт археологічних культур цього регіону.

За доби пізньої бронзи кількість петрогліфів з кіньми збільшується, в основному вони зображуються запряжними до колісниць [Таинство 2014, с. 230]. Образ колісниці, іiі частин і коня в цей час дуже міцно пов'язані один з одним та нерідко символізують один одного.

Міфопоетична формула «коні біля жертовного стовпа (світового дерева)», «володар коней», «господиня коней» та інші подібні відносяться О.Ю. Кузьміною до індоєвропейських народів періоду єдності [Кузьмина 1977, с. 39]. Сюжет «коні у світового дерева» поєднує зображення протипоставлених коней або інших тварин зі світовим деревом (конов'язь), яке, на думку В.В. Іванова, часто ототожнюється 3 антропоморфними образами (рис. 3) [Иванов 1974, с. 76-77]. В. Новоженов допускає, що цей образ міг скластися ще за часів перших успіхів доместикації [Таинство 2014, с. 230], але на петрогліфах, можливо поки що, його виявлено лише за часів пізньої бронзи. До сюжету «пан/господиня коней» семантично відносяться брати-близнюки Ашвіни-Діоскури, яких зображували стоячими перед богинею в образі двох вершників, нерідко їх замінювали двоє коней або дві кінські голови. О.Ю. Кузьміна вважає, що ці вершники - супутники богині - уособлювали протилежні стихії - життя і смерть, які підвладні матері-землі [Кузьмина 1977, с. 28-52]. Цікаву мандалу 3 Рігведи наводить В.В. Іванов [Иванов 1974, с. 131]:

«Відкрийся, о Ванаспаті (Володар лісу), подібно лону той, котра повинна народити; почуйте мій клич, о Ашвіни, та звільніть Сапта Вадхрі (того, у якого сім оскоплених жеребиів) ... Своєю таємничою силою, ви (Ашвіни) рухаєте деревом у дві протилежні сторони».

Коментуючи останній текст, О. В'єнно відзначила, що, «легко було б розглядати це деревостовп, як опору для сонця, що розгойдується у напрямку схід та захід [Иванов 1974, с. 131].

Встановлено, що принесення в жертву коней у світового дерева має індоєвропейське коріння [Иванов 1974, с. 92] та найбільш повно виражене у складному обряді asvamedha, що зафіксований у ведичних творах Ригведи, Яджурведи, а також у пізніших текстах (Махабхарата). Жертовний стовп у Ригведі однаково тісно пов'язаний як з першопочатковим ритуалом принесення жертви, так і з образом світового дерева, за яким дух жертви спрямовується вгору до відповідного бога. Одна 3 назв цього стовпа - asvattha перекладається як «стовп, до якого прив'язують коня, призначеного для жертви» [Иванов 1974; Шер 1978, с. 267].

Пов'язаними з asvamedha також є зображення козлів, які інтерпретуються як попередні або супутні коню жертви. Загалом у індоаріїв існувала певна ієрархія цінності істоти для 


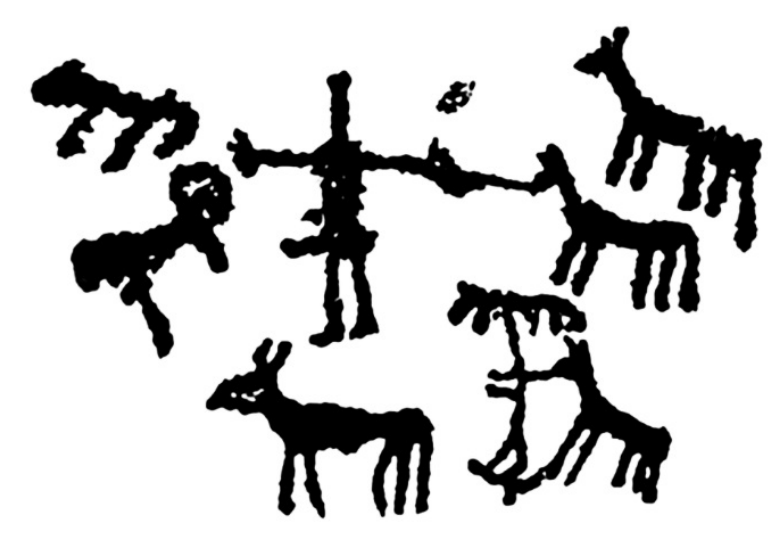

1
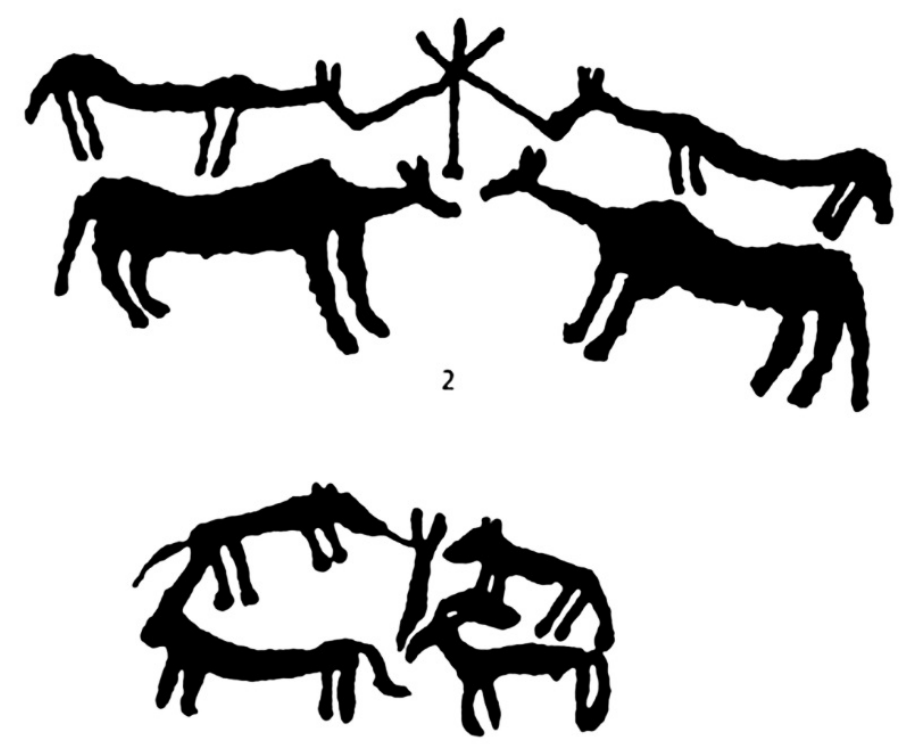
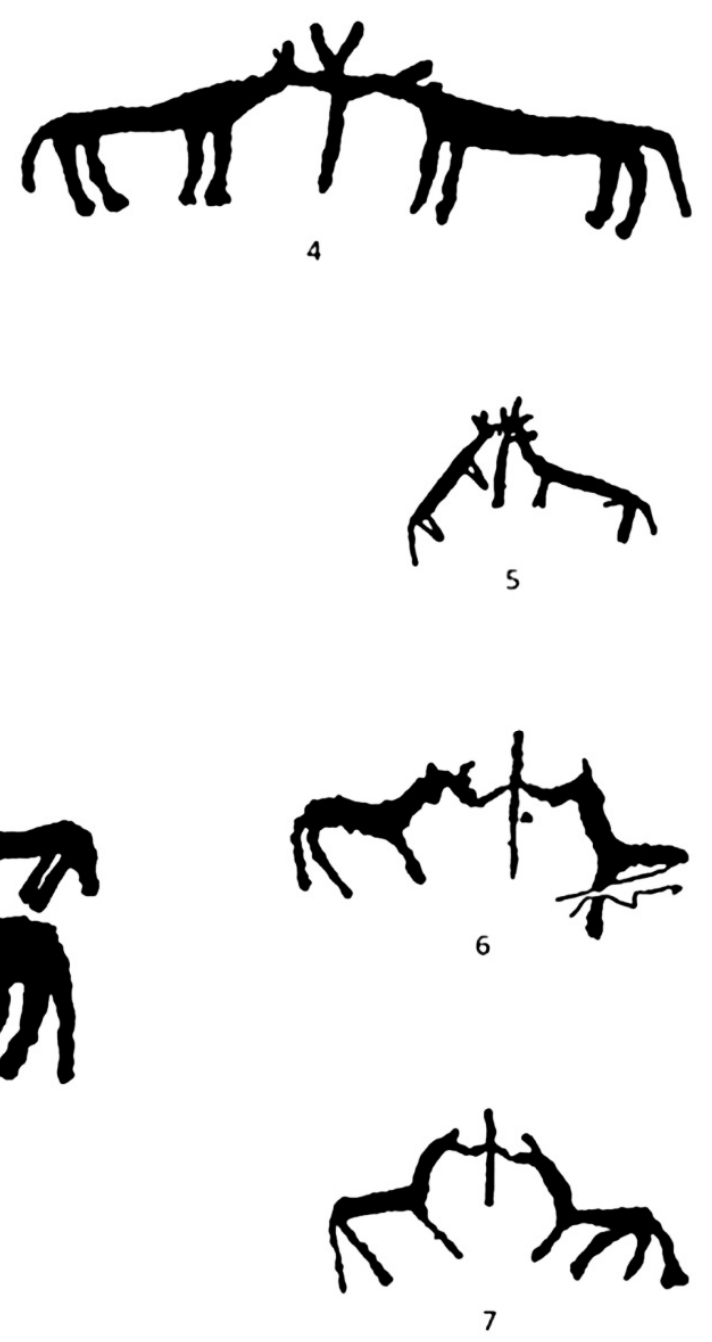

Рис. 3. Петрогліфи: 1 - Талас, Жалтирак-Таш; 2-4 - Тепсей, гирло р. Туби, правий берег Єнісею; 5 - Снісей, малюнок на плиті з могильника Варга; 6, 7 - Східний Казахстан [за: Шер 1993, с. 19]

Fig. 3. Petroglyphs: 1 - Talas, Zhaltyrak Tash; 2-4 - Tepey, mouth of the river Tubi, right bank of the Yenisei; 5 - Yenisei, drawing on a plate from the burial ground Varg; 6, 7 - Eastern Kazakhstan [after: Шep 1993, c. 19]

жертвоприношення людина-кінь-бик-баран-козел [Новоженов 2012, с. 349]. Білий кінь у цьому ритуалі виступає у ролі світової тварини коня Тваштра [Иванов 1974, с. 116]. Козел, як тварина меншого рангу, фігурує як жертовна доля Пушана, бога-посередника між небом та землею; саме він - Пушан - веде жертовного коня до місця жертвоприношення [Иванов 1974, c. 116]. Два знаки у вигляді гантелей, зображені на петрогліфі з урочища Мойнак (рис. 4,1 ), на думку 3.С. Самишева, можна інтерпретувати як дві точки міфологічного простору - верх та низ, між якими лежить шлях Пушана на колісниці, до якої впряжено козлів. Дві фігури гірських козлів у композиції можуть бути трактовані як жертовна доля Пушана, а кінь (собака?) як жертвоприношення Богу Сонця [Самашев 1992, с. 195-196]. Подібна інтерпретація підтверджується поховальними комплексами, зокрема шанським могильником Гоцзячшуан 

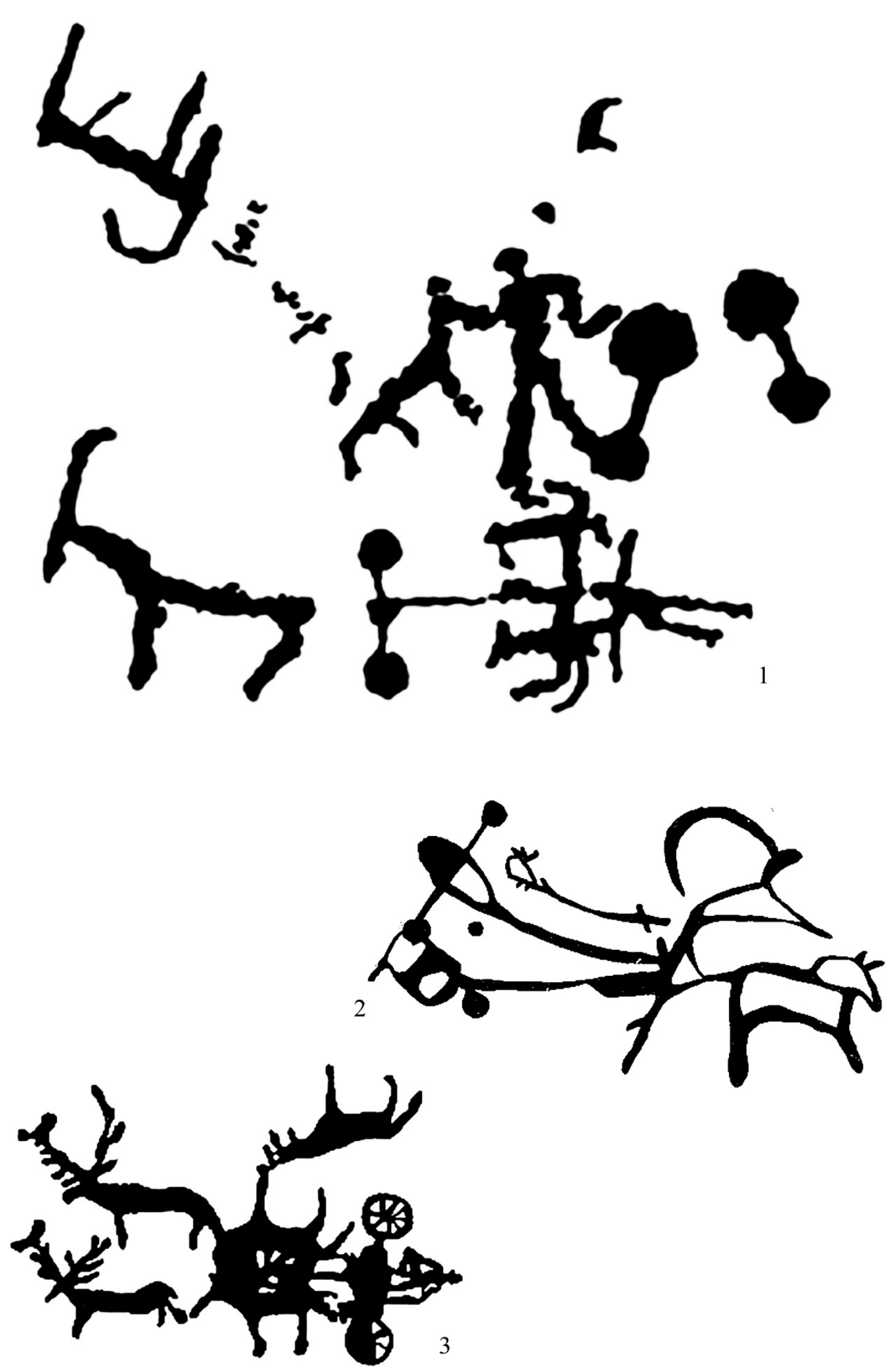

Рис. 4. Фантастичні колісниці: 1 - Урочище Мойнак [за: Самашев 1992, с. 79]; 2 - Колісниця з ріки Чулуут [за: Новгородова 2012, с. 69]; 3 - Колісниця з ріки Чулуут [за: Черемсин 2009, с. 68]

Fig. 4. Fantastic Chariots: 1 - Moinak monument [after: Самашев 1992, c. 79]; 2 - Chariot from Choletu river [after: Новгородова 2012, с. 69]; 3 - Chariot from Choletu river [after: Черемсин 2009, с. 68] 
[Новоженов 2012, с. 338]. Цікавим у цьому сенсі видається петрогліф на річці Чулуут (Монголія), опублікований Е.А. Новгородовою (рис. 4, 2) [Новгородова 2012, с. 69]. Слід додати, що деякі петрогліфи з «фантастичними упряжками» [Пяткин и др. 1990, с. 166-167] відносять до ямно-афанасіївської образотворчої традиції [Новоженов 2012, с. 218], але основними діючими персонажами в них виступають гірські козли та бики.

Цікавим є питання маскування коня оленем. Це явище насамперед відоме за матеріалами Пазирикських курганів, де були знайдені кістяки коней у масках оленів, що хронологічно відносяться до доби раннього заліза (рис. 5). Проте було виявлено цілий пласт аналогічних петрогліфів доби бронзи (рис. 4, 3) [Черемсин 2009, с. 355].

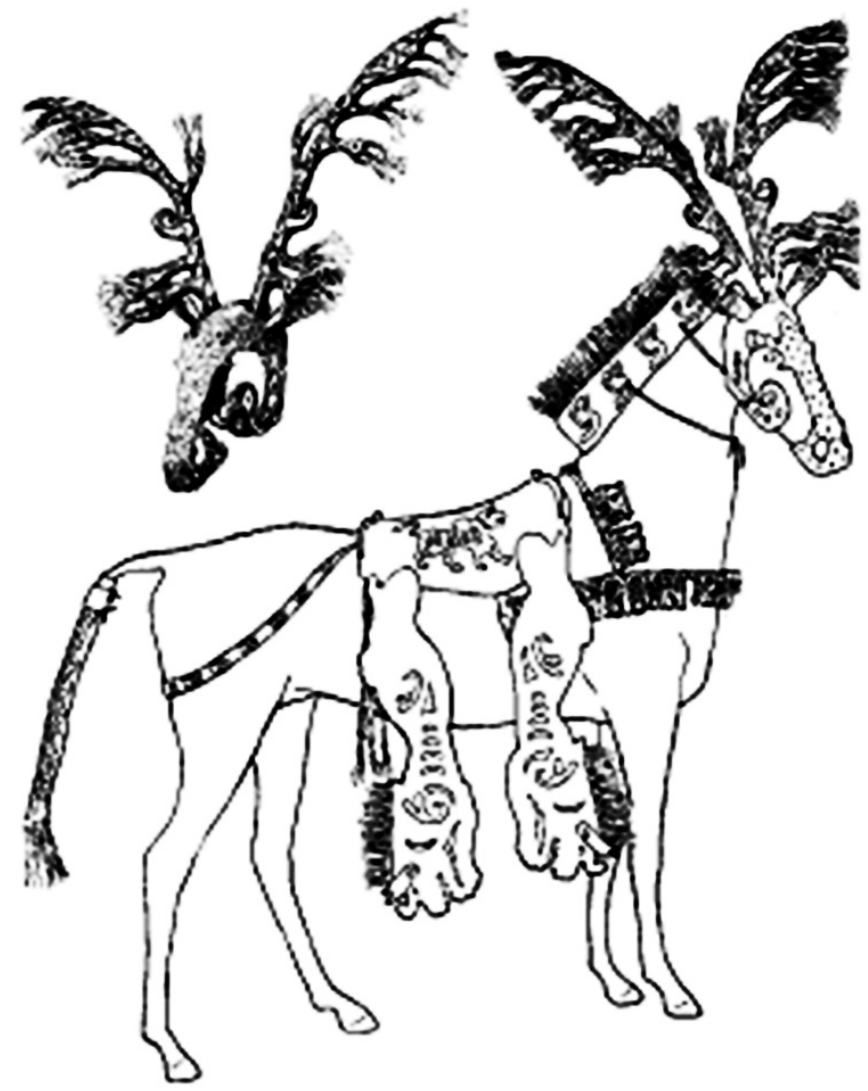

Рис. 5. Маска коня № 10 з Першого Пазирикського кургану. Реконструкція М.П. Грязнова [за: Черемсин 2009, с. 353]

Fig. 5. Mask of the horse number 10 from the first Paziyk burial mound. Reconstruction of M.P. Gryaznov [after: Черемсин 2009, с. 353]

Інтерпретацій пазирикських коней-оленів існує чимало. Під впливом теорій М.Я. Марра щодо первинності оленярства відносно конярства, в них бачили пережитки далеких часів [Черемсин 2009, с. 353]. Аналізуючи цей образ, Д. В. Черемсін, вдаючись до індоєвропейських міфологем, вбачає у цьому ритуалі наділення свійського коня силами дикої тварини, яка у багатьох народів має вищий сакральний статус [Черемсин 2009, с. 360-361]. Д.В. Черемсін звертає увагу на працю В.В. Іванова [Иванов 1974, с.75138], який ототожнює образ оленя зі світовим деревом [Черемсин 2009, с. 356], але дослідник чомусь не розвиває цю аналогію у своїй праці, хоча вона може бути досить перспективною. Кінь у масці оленя, якщо відштовхуватися від думки В.В. Іванова, стає ототожненням світового дерева та світової тварини - коня Тваштра, виступаючи своєрідним еквівалентом скандинавського світового дерева Ігдрасиль, назва якого перекладається В.В. Івановим як «ясень коня Одіна» [Иванов 1974, с. 112]. Попри розбіжності в інтерпретаціях цього ритуалу, він все одно має розглядатися як прояв культу коня наприкінці доби бронзи - на початку доби раннього заліза.

Висновки. Отже, петрогліфи є дуже складним та багатомірним джерелом, яке несе в собі світогляд і систему мислення своїх творців, повне розуміння яких, напевно, ніколи не вдасться відтворити, а це, у свою чергу, буде викривляти будь-які висновки. Але все ж таки з певною умовністю можна побачити, що набуття конем культового статусу відбувається поетапно, від об'єкта полювання до свійської упряжної тварини, що разом 3 колісницею символізує переміщення бога i, нарешті, до світової тварини, що асоціюється з царем і богами. Детальніше вивчення та розмежування цих етапів $є$ перспективою подальших досліджень.

Курзенков М.С.

\section{КОНЬ НА ПЕТРОГЛИФАХ БРОНЗОВОГО ВЕКА ЦЕНТРАЛЬНОЙ АЗИИ}

Изучение наскальных изображений является важной составляющей в реконструкции быта, верований, мифологических и эстетических представлений древних людей. Одним из вопросов на который может помочь дать ответ петроглифы - это распространение в этом регионе культа коня, что видится многими археологами одним из индикаторов пребывания и влияния индоевропейского блока культур. Целью статьи является поиск маркеров отображения культа коня в пласте петроглифов Центральной Азии. 
В статье проведен анализ ключевых сюжетов петроглифов, связанных с образом коня. Рассматриваются такие сюжетные блоки, как «конь у мирового дерева», «небесные фантастические колесницы», сюжетно-концептуальные пары конь-собака, конь-козел, конь-змея, изображения коня в виде оленя и т.п., сопоставляя их с мифами и ритуальными практиками индоевропейцев, сохранившихся в письменных источниках, делается попытка их интерпретации.

Учитывая проведенный анализ, можно сделать вывод, что культ коня в классическом понимании окончательно закрепился в Центральной Азии только в эпоху поздней бронзы. Прослеживаются определенные этапы формирования культа, от объекта охоты до упряжного животного, которое вместе с колесницей символизирует перемещение бога, и, наконец, к мировому животному, которое, в свою очередь, ассоциируется с царем и богами.

Ключевые слова: бронзовый век, сейминсько-турбинский феномен, петроглиф, культ коня, индоевропейцы, ашвамедха, Ашвины-Диоскуры.

\section{Kurzenkov M.S.}

\section{HORSE ON BRONZE AGE PETROGLYPHS IN CENTRAL ASIA}

The study of rock paintings is an important component in the reconstruction of daily life, beliefs, mythological and aesthetic representations of ancient people. One of the questions that petroglyphs can help to answer is the spread of the horse cult in Central Asia, which many archaeologists understand as one of the indicators of the presence and influence of the Indo-European cultures. The purpose of the article is to search for the markers of the cult of the horse in the set of petroglyphs of Central Asia.

The article analyzes the key plots of petroglyphs associated with the image of the horse. From petroglyphs depicting a horse in the context of a hunt in its wild, non-domesticated form, to sled animals in chariots and scenes related to ritual actions regarding the horse. I consider such plot blocks as the horse near the world tree, the heaven chariots, the conceptual pairs horse-dog, horse-goat, horse-snake, horse images in the form of a deer, etc. are compared with the myths and ritual practices of the Indo-Europeans represented in written records in order to make an attempt to interpret them.

Considering the results of analysis, it can be concluded that the cult of the horse in the classical sense was completly entrenched in Central Asia only in Late Bronze Age. Certain stages of the formation of the cult are traced, from the object of the hunt to the harness of animals. Combined with a chariot it symbolizes the movement of the god and, finally, to the world animal, which in turn is associated with the king and the gods.

Keywords: Bronze Age, Seimino-Turbino phenomenon, petroglyph, horse cult, Indo-Europeans, Ashwamedha, Ashwins-Dioscuri.

\section{СПИСОК ДЖЕРЕЛ I ЛІТЕРАТУРИ}

Археология, этнография и антропология Евразии: Научный журнал. Специальный номер // Проблемы изучения первобытного искусства [материалы дискуссии]. - Новосибирск, 2009.

Гамкрелидзе Т.В. Индоевропейский язык и индоевропейцы / Т.В. Гамкрелидзе, В.В. Иванов. Тбилиси: Изд-во Тбилисского ун-та, 1984. - 1409 с.

Дэвлет Е.Г. Сокровища наскального искусства Северной и центральной Азии / Е.Г. Дэвлет, М.А. Дэвлет. - М.: ИА РАН, 2011. - 382 с.

Иванов В.В. Опыт истолкования древнеиндийских ритуальных и мифологических терминов, образованных от asva - «конь» / В.В. Иванов // Проблемы истории языков и культуры народов Индии. - М., 1974. - С. 75-138.

Кубарев В.Д. Мифы и ритуалы, запечатленные в петроглифах Алтая / В.Д. Кубарев // АЭАЕ. 2006. - № 3. - С. 41-54.

Кузьмина Е.Е. Конь в религии и искусстве саков и скифов / Е.Е. Кузьмина // Скифы и сарматы. - К.: Наук. думка, 1977. - С. 96-119.

Кузьмина Е.Е. Распространение коневодства и культа коня у ираноязычных племен Средней Азии и других народов Старого света / Е.Е. Кузьмина // Средняя Азия в древности и Средневековье [история и культура]. Под ред. Б.Г. Гафурова, Б.А. Литвинского. - М.: Наука, 1977. - С. 28-52.

Молодин В.И. Памятник Сопка-2 на реке Оми / В.И. Молодин, А.И. Соловьев. - Т. 2: Культурно-хронологический анализ погребальных комплексов эпохи средневековья. - Новосибирск: Изд-во ИАЭТ СО РАН, 2004. - 182 с.

Новгородова Э.А. Мир петроглифов Монголии / Э.А. Новгородова. - М.: ГРВЛ, 1984. - 168 с.

Новоженов А.В. Чудо комуникации и древнейший колесный транспорт Евразии / А.В. Новоженов. - М., 2012. -500 с. 
Пяткин Б.Н. Сейминско-турбинская изобразительная традиция: пластика и петроглифы / Б.Н. Пяткин, Е.А. Миклашевич // Проблемы изучения наскальных изображений в СССР. - М., 1990. - С. 146-153.

Савинов Д.Г. Некоторые аспекты теоретического изучения петроглифов [по материалам Центральной Азии и Южной Сибири] / Д.Г. Савинов // АЭАЕ. - 2000. Специальный выпуск. 2 [2] С.150-161.

Самашев 3.С. Наскальные изображения Верхнего Прииртышья / 3.С. Самашев. - Алма-Ата: Гылым, 1992. - 288 с.

Таинство этнической истории древнейших номадов степной Евразии / сост. В.А. Новоженов, гл. ред. проф. А.В. Епимахов. - Алматы: Остров Крым, 2014. - 454 с.

Черемсин Д.В. О семантике маскированных рогатых лошадей Пазырыкских курганов / Д.В. Черемсин // АЭАЕ. - Специальный номер, 2009. - С. 352-362.

Шер Я.А. Господин коней на берегу Енисея / Я.А. Шер // ПАВ. - 1993. - № 6. - С.17-22.

Шер Я.А. К интерпретации сюжетов некоторых петроглифов Саймалы-Таша / Я.А. Шер. // Культура Востока. Древность и раннее средневековье. - Л., 1978. - С. 163-171.

Шер Я.А. Петроглифы Средней и Центральной Азии / Я.А. Шер. - М.: Наука, 1980. - 328 с.

Dani A.H. History of Civilizations of Central Asia / Dani A.H., V.M. Masson. - Paris: UNESCO, 1992. - 535 p.

\section{REFERENCES}

Arheologiya, etnografiya i antropologiya Evrazii: Nauchnyiy zhurnal. Spetsialnyiy nomer // Problemyi izucheniya pervobyitnogo iskusstva [materialyi diskussii]. - Novosibirsk, 2009.

Gamkrelidze T.V. Indoevropeyskiy yazyik i indoevropeytsyi / T.V. Gamkrelidze, V.V. Ivanov. Tbilisi: Izd-vo Tbilisskogo un-ta, 1984. - 1409 s.

Devlet E.G. Sokrovischa naskalnogo iskusstva Severnoy i tsentralnoy Azii / E.G. Devlet, M.A. Devlet. - Moskva: IA RAN, 2011. - $382 \mathrm{~s}$.

Ivanov V.V. Opyit istolkovaniya drevneindiyskih ritualnyih i mifologicheskih terminov, obrazovannyih ot asva - «kon» / V.V. Ivanov // Problemyi istorii yazyikov i kulturyi narodov Indii. - Moskva, 1974. - S. 75-138.

Kubarev V.D. Mifyi i ritualyi, zapechatlennyie v petroglifah Altaya / V.D. Kubarev // Arheologiya, etnografiya i antropologiya Evrazii. - 2006. - N 3. - S. 41-54.

Kuzmina E.E. Kon v religii i iskusstve sakov i skifov / E.E. Kuzmina // Skifyi i sarmatyi. - Kiev, 1977. - S. 96-119.

Kuzmina E.E. Rasprostranenie konevodstva i kulta konya u iranoyazyichnyih plemen Sredney Azii i drugih narodov Starogo sveta / E.E. Kuzmina // Srednyaya Aziya v drevnosti i Srednevekove [istoriya i kultura]. Pod red. B.G. Gafurova, B.A. Litvinskogo. - Moskva: Nauka, 1977. - S. 28-52.

Molodin V.I. Pamyatnik Sopka-2 na reke Omi / V.I. Molodin, A.I. Solovev. - T. 2: Kulturno-hronologicheskiy analiz pogrebalnyih kompleksov epohi srednevekovya. Novosibirsk: Izd-vo IAET SO RAN, 2004. - $182 \mathrm{~s}$.

Novgorodova E.A. Mir petroglifov Mongolii / E.A. Novgorodova. - Moskva: GRVL, 1984. - 168 s.

Novozhenov A.V. Chudo komunikatsii i drevneyshiy kolesnyiy transport Evrazii / A.V. Novozhenov. - Moskva, 2012. - $500 \mathrm{~s}$.

Pyatkin B.N. Seyminsko-turbinskaya izobrazitelnaya traditsiya: plastika i petroglifyi / B.N. Pyatkin, E.A. Miklashevich // Problemyi izucheniya naskalnyih izobrazheniy v SSSR. - Moskva, 1990. - S. 146-153.

Savinov D.G. Nekotoryie aspektyi teoreticheskogo izucheniya petroglifov [po materialam Tsentralnoy Azii i Yuzhnoy Sibiri] / D.G. Savinov // Arheologiya, etnografiya i antropologiya Evrazii. Sibirskoe otdelenie Rossiyskoy akademii nauk Institut arheologii i etnografii. - Spetsialnyiy vyipusk. 2 [2] 2000. - S.150-161.

Samashev Z.S. Naskalnyie izobrazheniya Verhnego Priirtyishya / Z.S. Samashev. - Alma Ata: Gyilyim, 1992. - 288 s.

Cheremsin D.V. O semantike maskirovannyih rogatyih loshadey Pazyiryikskih kurganov / D.V. Cheremsin // Arheologiya etnografiya i antropologiya Evrazii. - Spetsialnyiy nomer, 2009. - S. 352-362.

Sher Ya.A. Gospodin koney na beregu Eniseya / Ya.A. Sher // PAV. - 1993. - № 6. - S.17-22.

Sher Ya.A. K interpretatsii syuzhetov nekotoryih petroglifov Saymalyi-Tasha / Ya.A. Sher. // Kultura Vostoka. Drevnost i rannee srednevekove. - Leningrad, 1978. - S. 163-171.

Sher Ya.A. Petroglifyi Sredney i Tsentralnoy Azii / Ya.A. Sher. - Moskva: Nauka, 1980. - 328 s.

Tainstvo etnicheskoy istorii drevneyshih nomadov stepnoy Evrazii. pod red. prof. A.V. Epimahova, sost. V.A. Novozhenov. - Almatyi, 2014. 454 s.

Dani A.H. History of Civilizations of Central Asia / A.H. Dani, V.M. Masson. - Paris: UNESCO, 1992 - 535 p. 